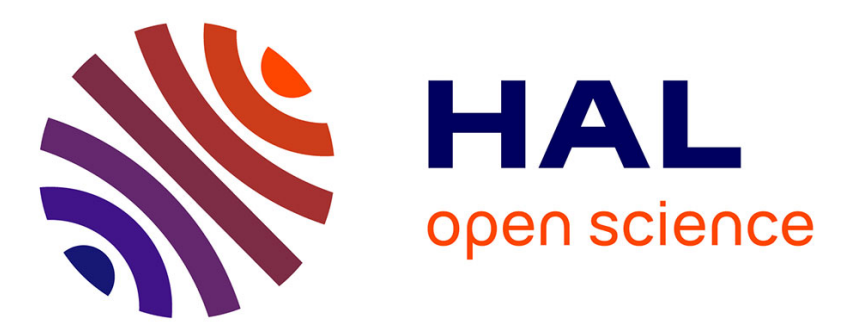

\title{
Natural Gas - an Environmentally Friendly Fuel for Urban Vehicles: the Smart Demonstrator Approach
}

\author{
R. Tilagone, S. Venturi, G. Monnier
}

\section{To cite this version:}

R. Tilagone, S. Venturi, G. Monnier. Natural Gas - an Environmentally Friendly Fuel for Urban Vehicles: the Smart Demonstrator Approach. Oil \& Gas Science and Technology - Revue d'IFP Energies nouvelles, 2006, 61 (1), pp.155-164. 10.2516/ogst:2006010x . hal-02005794

\section{HAL Id: hal-02005794 https://hal-ifp.archives-ouvertes.fr/hal-02005794}

Submitted on 4 Feb 2019

HAL is a multi-disciplinary open access archive for the deposit and dissemination of scientific research documents, whether they are published or not. The documents may come from teaching and research institutions in France or abroad, or from public or private research centers.
L'archive ouverte pluridisciplinaire HAL, est destinée au dépôt et à la diffusion de documents scientifiques de niveau recherche, publiés ou non, émanant des établissements d'enseignement et de recherche français ou étrangers, des laboratoires publics ou privés. 


\title{
Natural Gas - an Environmentally Friendly Fuel for Urban Vehicles: the Smart Demonstrator Approach
}

\author{
R. Tilagone' ${ }^{1}$ S. Venturi ${ }^{1}$ and G. Monnier ${ }^{2}$ \\ 1 IFP-Lyon, BP 3, 69390 Vernaison - France \\ 2 Institut français du pétrole, 1 et 4, avenue de Bois-Préau, 92852 Rueil-Malmaison Cedex - France \\ e-mail: richard.tilagone@ifp.fr - stephane.venturi@ifp.fr - gaetan.monnier@ifp.fr
}

Résumé - Le gaz naturel, un carburant adapté pour les véhicules urbains : cas du démonstrateur Smart - La réduction des gaz à effet de serre est un objectif important qui concerne l'ensemble des consommateurs dont notamment le secteur industriel.

En ce qui concerne l'automobile, l'engagement pris par les constructeurs européens (diminution des émissions de $\mathrm{CO}_{2}$ émis par le parc commercialisé à $140 \mathrm{~g} / \mathrm{km}$ sur cycle normalisé d'ici 2008) répond aux recommandations de la Commission européenne en la matière.

La réduction sensible du $\mathrm{CO}_{2}$ émis par les automobiles nécessite une réduction de la consommation globale de carburant. L'utilisation de carburants avantageux sur le plan du rapport H/C est également une voie efficace. Une solution technologique pertinente pour la réduction de la consommation spécifique des moteurs consiste à en réduire la cylindrée, approche communément appelée «downsizing » ou «éco-suralimentation ». Compte tenu de ses propriétés physico-chimiques, le gaz naturel est un carburant parfaitement adapté pour réduire ces émissions de $\mathrm{CO}_{2}$; il présente en effet un rapport $\mathrm{H} / \mathrm{C}$ élevé (proche de 4) permettant un gain de l'ordre de $23 \%$, et des réglages de la combustion à très haut rendement (indice d'octane proche de 130).

L'objectif majeur de ce projet a été de démontrer l'intérêt du gaz naturel en tant que carburant vis-à-vis de la réduction des émissions de $\mathrm{CO}_{2}$. La première étape a consisté à optimiser le moteur pour un fonctionnement dédié (pistons pour un rapport volumétrique de compression augmenté, bielles renforcées, vilebrequin, etc.), puis la combustion a été optimisée grâce à des essais au banc moteur où les cartographies de base ont été réalisées. La suralimentation par turbocompresseur et le calage de distribution ont été particulièrement travaillés pour maintenir des performances en puissance comparable au moteur essence. L'optimisation s'est poursuivie sur le véhicule dont les derniers résultats obtenus confirment le faible niveau de $\mathrm{CO}_{2}, 90 \mathrm{~g} \mathrm{CO} / \mathrm{km}$ ce qui représente une diminution de $27 \%$ par rapport à l'essence, le respect des normes EURO IV et un agrément de conduite conforme aux attentes client.

\footnotetext{
Abstract - Natural Gas - an Environmentally Friendly Fuel for Uurban Vehicles: the Smart Demonstrator Approach - The reduction of greenhouse gases emissions remains one of the most important challenges stakes for the next decades involving all energy consumers and especially the industrial actors, although the need to make better use of energy is not appreciated to the same extent by all industrial countries.

For the automotive sector, the European car manufacturers' commitment (reduction of the average fuel consumption for new vehicles to 140 grams of $\mathrm{CO}_{2}$ produced per kilometer by 2008) appears to be a valuable contribution towards meeting the recommendations of the European Commission.
} 
A sharp $\mathrm{CO}_{2}$ emission reduction requires efforts both to reduce vehicle's fuel consumption, and to widen the use of fuel with advantageous molecular hydrogen to carbon $(\mathrm{H} / \mathrm{C})$ ratio. Alongside vehicle's optimization itself, improving engine efficiency remains the main target. Reduction of engine displacement volume (commonly named downsizing) is an efficient way to achieve this target. Due to its interesting chemical properties, Natural Gas can be used to achieve low carbon dioxide levels (H/C ratio close to 4), while at the same time maintaining high thermal efficiency through dedicated engine development.

The main objective of this project is to confirm (with a dedicated demonstrator vehicle) the high efficiency of CNG fuel when used in urban conditions. The target is to achieve low $\mathrm{CO}_{2}$ emissions with a maximum level of $90 \mathrm{~g} / \mathrm{km}$ on the MVEG driving cycle, while keeping pollutant emissions below EURO IV level.

The first step was dedicated to CNG specific engine parts design (pistons, connecting rod, crankshaft, etc.) in order to optimize CNG configuration. During the following steps, the engine has been optimized on a test bench. Valve timing and turbocharger selection have been optimized in order to obtain the best trade-off in terms of power, consumption and pollutants. The final step has been spent to calibrate the engine, firstly on the test bench and secondly on the vehicle. This work allows coping with EURO IV emissions level with optimized catalyst light-off, transient running conditions, driveability, etc.

\section{INTRODUCTION}

For many decades, Natural Gas has been used as a reliable, safe and efficient fuel for transportation, in favor of emission reduction of greenhouse and toxic gases. Today, Natural Gas resources are equivalent to oil resources in terms of energy ready to be exploited, and with homogeneous distribution on the earth.

It has been demonstrated that local emissions from Natural Gas vehicles present low reactivity and toxicity. Figure 1 compares the potential of ozone formation taking into account types of exhaust gases emitted by conventional vehicles: gas fuels remain the most promising.

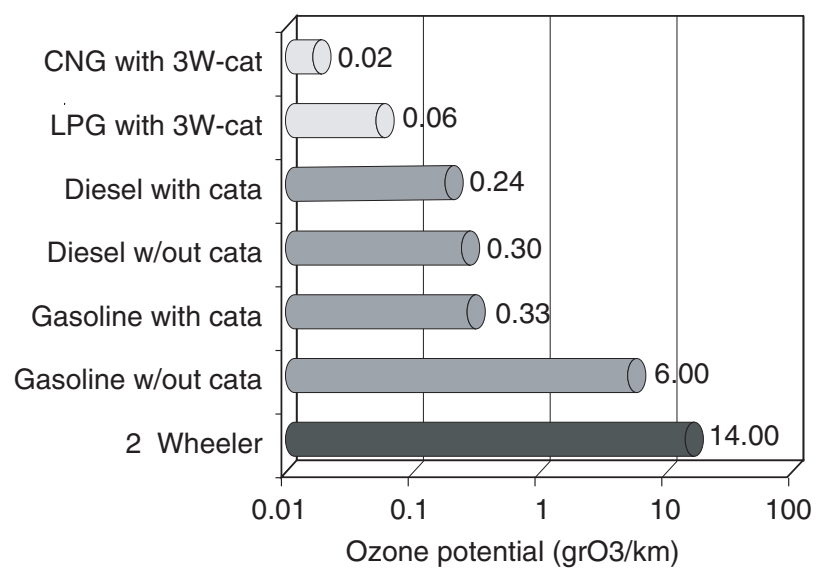

Figure 1

Ozone potential for several vehicles.
Mainly composed of methane (between $80 \%$ to $98 \%$ ), Natural Gas has a high Research Octane Number (RON), higher than 120 as compared to 95 for European Eurosuper premium gasoline, leading to high knocking resistance. Thanks to this characteristic, the engine can be designed with a higher compression ratio than for conventional gasoline engines and Maximum Best Torque (MBT) advances can be selected with continuous stoichiometric conditions whatever the load and engine speed.

These key factors enhance thermal efficiency and permit exhaust emissions to be reduced especially for turbocharged engines. For instance, raw unburned hydrocarbon emissions are $50 \%$ smaller than those of the gasoline baseline engine. The gaseous state avoids the wall-wetting effect on the intake manifold and cylinder liner especially at cold start conditions and limits oil film adsorption-desorption phenomena.

Moreover, due to the $\mathrm{H} / \mathrm{C}$ molecular ratio close to four, $\mathrm{CO}_{2}$ emissions at stoichiometric conditions are $23 \%$ lower than for gasoline (for the same energy introduced into the combustion chamber), Table 1.

These advantages are highlighted by several Well-toWheel analyses as shown in the EUCAR-Concawe-JRC study published in 2003, Figure 2, which reveals Natural Gas as a promising way to reduce equivalent $\mathrm{CO}_{2}$ emissions. Natural Gas offers a real alternative to fulfil European Car Manufacturers commitments, which aim to reduce $\mathrm{CO}_{2}$ emissions from European cars on the road to $140 \mathrm{~g} / \mathrm{km}$ by 2008 . This remains ambitious however considering the gains already obtained by small gasoline and Diesel vehicles on the European traffic.

Alongside the benefits of using Natural Gas, some drawbacks should be mentioned:

- Depending on the gas field location and the gas supplier's strategy on the commercial network, characteristics vary 
TABLE 1

Theoretical $\mathrm{CO}_{2}$ emissions for stoichiometric combustion

\begin{tabular}{|c|c|c|c|c|c|c|}
\hline \multirow[b]{2}{*}{ Natural Gas } & \multirow{2}{*}{$\begin{array}{c}\mathrm{H} / \mathrm{C} \\
3.7 / 3.9\end{array}$} & \multicolumn{2}{|c|}{$\begin{array}{c}\mathrm{CO}_{2} \\
\text { (gr/gr of fuel) }\end{array}$} & \multirow{2}{*}{$\begin{array}{c}\begin{array}{c}\mathrm{LHV} \\
(\mathrm{kJ} / \mathrm{kg}\end{array} \\
48,444\end{array}$} & \multicolumn{2}{|c|}{$\begin{array}{c}\mathrm{CO}_{2} \\
(\mathrm{gr} / \mathrm{kJ}) \times 1000\end{array}$} \\
\hline & & 2.75 & $-13.5 \%$ & & 56.8 & $-23.8 \%$ \\
\hline LPG $(50 / 50)$ & 2.5 & 3.03 & $-4.7 \%$ & 46,055 & 65.8 & $-11.7 \%$ \\
\hline Diesel fuel & 1.9 & 3.17 & $-0.3 \%$ & 42,769 & 74.1 & $-0.5 \%$ \\
\hline Gasoline & 1.8 & 3.18 & - & 42,690 & 74.5 & - \\
\hline
\end{tabular}

in accordance with Natural Gas composition. Fortunately however, whatever the Natural Gas variation (Air/Fuel ratio, Low Heat Value and knock Index), the energy held in a fixed equivalence ratio, and consequently the rated power from the engine equipped with an Air/fuel ratio close-loop control system, are not greatly affected.

- Obviously, Low Heat Value may affect driving range, and so, a high capacity tank and high pressure are necessary for gaseous storage. For instance, with a storage pressure of $20 \mathrm{MPa}$, the volume necessary for the same energy on board is four times as big compared to gasoline, Table 2 .

\section{STOICHIOMETRIC TURBOCHARGED SMALL ENGINES: THE DOWNSIZING APPROACH}

The reduction of the engine's size is an efficient way to reduce specific consumption by reducing friction losses for engine load controlled by a throttle, and promoting better efficiency conditions (higher loads).

For instance, to drive a mid-range vehicle at a constant speed of $70 \mathrm{~km} / \mathrm{h}$, a conventional gasoline port injection engine should develop an output power of approximately $7 \mathrm{~kW}$. This output power represents at $2000 \mathrm{rpm}$ a Brake Mean Effective Pressure (BMEP) of 2 bars for a 2-Liter displacement engine and twice as much for a 1-Liter displacement engine. Figure 3 shows a representative Specific Fuel Consumption (SFC) map of a current conventional SI-PFI gasoline engine.

By assuming the assumption that specific fuel consumption for a given engine load does not change depending on the swept volume per unit, dividing the swept volume by 2 results for this simple case in reducing the specific consumption from $380 \mathrm{~g} / \mathrm{kWh}$ to $300 \mathrm{~g} / \mathrm{kWh}$ (look at the two colour points). In a real case, due to the increase of losses for a small size combustion chamber (heat transfer and relative friction losses), the benefit in terms of fuel consumption is less important, and so the resulting $\mathrm{CO}_{2}$ emissions reduction is between $15 \%$ and $20 \%$.

Nevertheless, limitation of size reduction is necessary to avoid requirement of too high BMEP, especially for gasoline application due to knock sensitivity and pollution. Moreover, reducing swept volume affects performances for naturally

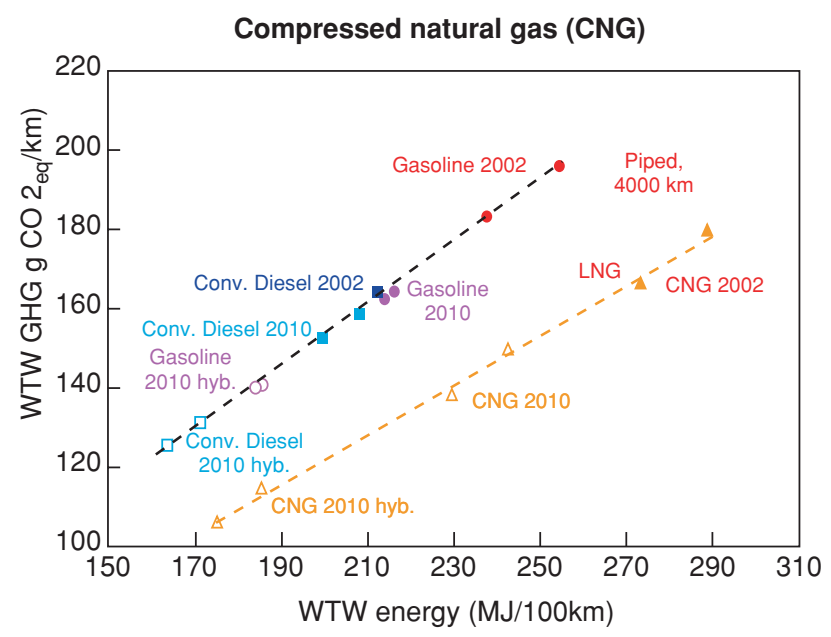

Figure 2

EUCAR-Concawe-JRC Well to Wheel analysis.

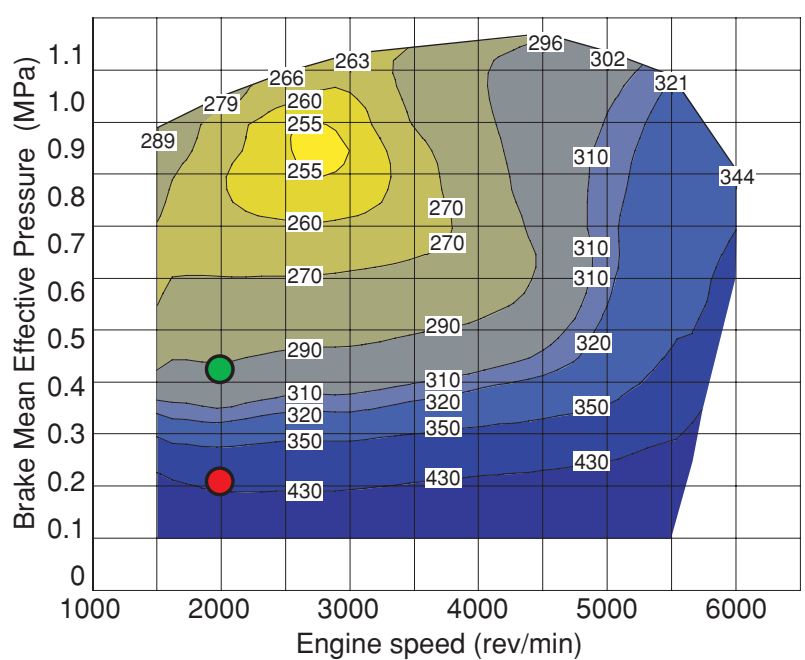

Figure 3

Specific consumption for a conventional medium size SI-FPI gasoline engine. 
TABLE 2

Energy per storage volume for common fuel

\begin{tabular}{l|c|c|c|c}
\cline { 2 - 4 } & $\begin{array}{c}\text { Density } \\
\mathrm{kg} / \mathrm{m}^{3}\end{array}$ & $\begin{array}{c}\text { LHV } \\
\mathrm{kg} / \mathrm{m}\end{array}$ & $\begin{array}{c}\text { Energy } \\
\mathrm{kg} / \mathrm{m}^{3}\end{array}$ & $\begin{array}{c}\text { Tank volume } \\
\text { for equivalent } \\
\text { energy stored }\end{array}$ \\
\hline Gasoline & 750 & 42,690 & 32,020 & - \\
\hline Diesel fuel & 835 & 42,770 & 35,710 & $\times \mathbf{0 . 9}$ \\
\hline $\begin{array}{l}\text { Gaseous } \mathbf{C H}_{\mathbf{4}} \\
1013 \mathrm{hPa}, 273 \mathrm{~K}\end{array}$ & 0.716 & 50,010 & 36 & $\times \mathbf{8 9 5}$ \\
\hline $\begin{array}{l}\text { Gaseous } \mathbf{C H}_{\mathbf{4}} \\
20,0 \mathrm{Mpa}, 293 \mathrm{~K}\end{array}$ & 173 & 50,010 & 8,652 & $\times \mathbf{3 . 7}$ \\
\hline
\end{tabular}

aspirated conditions, with more severe penalty for a Natural Gas engine due to the gaseous phase (volumetric efficiency could be affected by over $10 \%$ ).

The drop in performance can be partially removed with stoichiometric conditions, more suitable to cope with the stringent emissions regulation, using a proven three-way catalyst and with fewer penalties to control transient conditions. Using a supercharger is another efficient way to overcome this drawback.

In the case of a downsized turbocharged Natural Gas engine, the stoichiometric approach leads to a higher exhaust temperature in comparison to lean-burn approach, helpful both to optimize enthalpy of the exhaust gas and to reduce unburned hydrocarbon during the cold start-up phase.

\section{TECHNICAL FEATURES OF THE PRODUCTION SMART 600cc ENGINE}

The Smart vehicle offers characteristics proper to urban vehicles: small dimensions, light weight and low consumption helping to reduce $\mathrm{CO}_{2}$ emissions. Designed by SUPREX for $M C C$, the mechanical features of this 3 cylinder-in-line engine are as follows:

- bore x stroke: $63.5 \mathrm{~mm}$ x $63 \mathrm{~mm}$;

- gasoline compression ratio: 9.5:1.

Output performances announced by $M C C$ are attainable with the GT12 cooled turbocharger produced by AlliedSignal Automotive (GARRETT), allowing over-boost conditions. In this case, the intake manifold pressure is regulated to 2 bars instead of 1.8 bars:

- output Power: $40 \mathrm{~kW}$ at $5250 \mathrm{rev} / \mathrm{min}$;

- maximum Torque: $80 \mathrm{Nm}$ from $2000 \mathrm{rev} / \mathrm{min}$ to $4500 \mathrm{rev} /$ $\min$;

- maximum over boost Torque: $88 \mathrm{Nm}$ from $2000 \mathrm{rev} / \mathrm{min}$ to $4500 \mathrm{rev} / \mathrm{min}$.

The air coming from the compressor is cooled with a specific air/air cooler without any exhaust gas recirculation.
The same camshaft in the cylinder head (with hydraulic valve lift), driven with a chain actuates the two valves on each cylinder. The exhaust manifold includes a turbine house as shown in Picture 1, allowing thermal losses to be reduced, then the maximum of exhaust gas enthalpy to be obtained. Two spark plugs per cylinder stabilize the combustion at delayed spark advance.

\section{REFERENCE TESTS WITH THE SMART GASOLINE VEHICLE}

In order to establish reference data and to be able to quantify the real impact of using Natural Gas compared to gasoline fuel, many tests have been carried out at IFP. Tests on the chassis-dynamometer bench concern two gasoline vehicles: the first one unused and the second one underlining the impact of mileage.

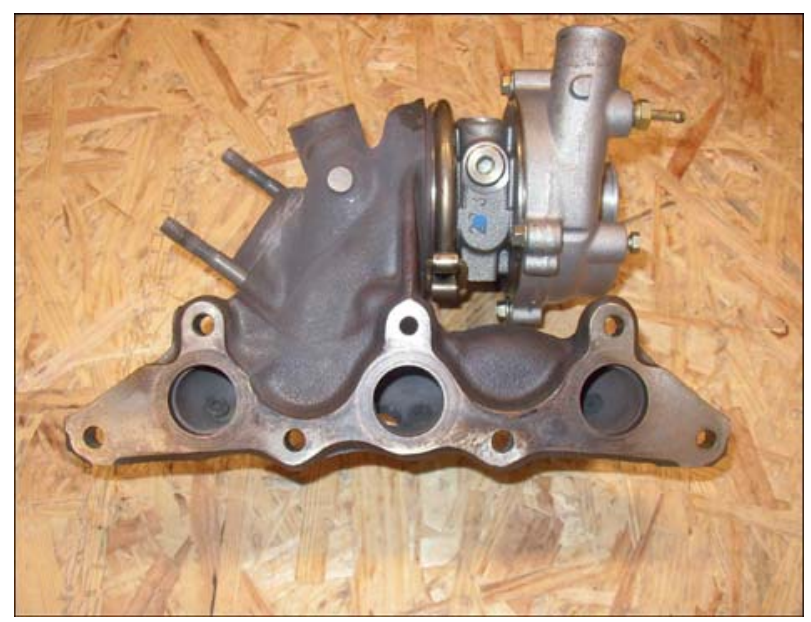

Picture 1

Exhaust manifold. 
Results obtained on the European Driving Cycle are similar to those found by UTAC, the company in charge of determining the drag and friction losses curve. They confirm that gasoline vehicle pollutant emissions meet the EURO IV regulation whatever the mileage, Table 3.

Nevertheless, $\mathrm{CO}_{2}$ emissions for the gasoline Smart are unexpected, with an increase between $10 \%$ and $15 \%$ in comparison to official figures, probably due to higher mechanical losses.

TABLE 3

UTAC and IFP NEDC results

\begin{tabular}{l|c|c|c|c|c}
\hline & $\begin{array}{c}\text { Mileage } \\
\mathrm{km}\end{array}$ & $\begin{array}{c}\mathbf{C O} \\
\mathrm{g} / \mathrm{km}\end{array}$ & $\begin{array}{c}\mathbf{H C} \\
\mathrm{g} / \mathrm{km}\end{array}$ & $\begin{array}{c}\mathrm{NOx} \\
\mathrm{g} / \mathrm{km}\end{array}$ & $\begin{array}{c}\mathbf{C O}_{\mathbf{2}} \\
\mathrm{g} / \mathrm{km}\end{array}$ \\
\hline \multicolumn{2}{c|}{ Euro IV - 2005 } & 1.00 & 0.10 & 0.08 & \\
\hline UTAC results & $\mathbf{3 , 1 5 0}$ & $\mathbf{0 . 2 6}$ & $\mathbf{0 . 0 8}$ & $\mathbf{0 . 0 4}$ & $\mathbf{1 4 0 . 5}$ \\
IFP results & $\mathbf{3 , 2 7 0}$ & $\mathbf{0 . 3 0}$ & $\mathbf{0 . 0 9}$ & $\mathbf{0 . 0 4}$ & $\mathbf{1 3 6 . 4}$ \\
IFP results & $\mathbf{5 2 , 2 2 0}$ & $\mathbf{0 . 3 8}$ & $\mathbf{0 . 0 6}$ & $\mathbf{0 . 0 5}$ & $\mathbf{1 3 1 . 7}$ \\
\hline
\end{tabular}

\section{BENCH RESULTS WITH A NATURAL GAS ENGINE}

Several mechanical adaptations were made before carrying out engine tests for an optimal use of the Natural Gas Vehicle. Modifications concern the compression ratio increase, from $9.5: 1$ to $12.0: 1$ and the setting up of the Natural Gas line.

Due to higher in-cylinder pressure (Best-Torque Spark Advance and higher compression ratio) new strengthened pistons have been designed and machined. Connecting rods have been modified too. Low-pressure Natural Gas injectors ( 4 bar) from Keihin have been selected. They needed

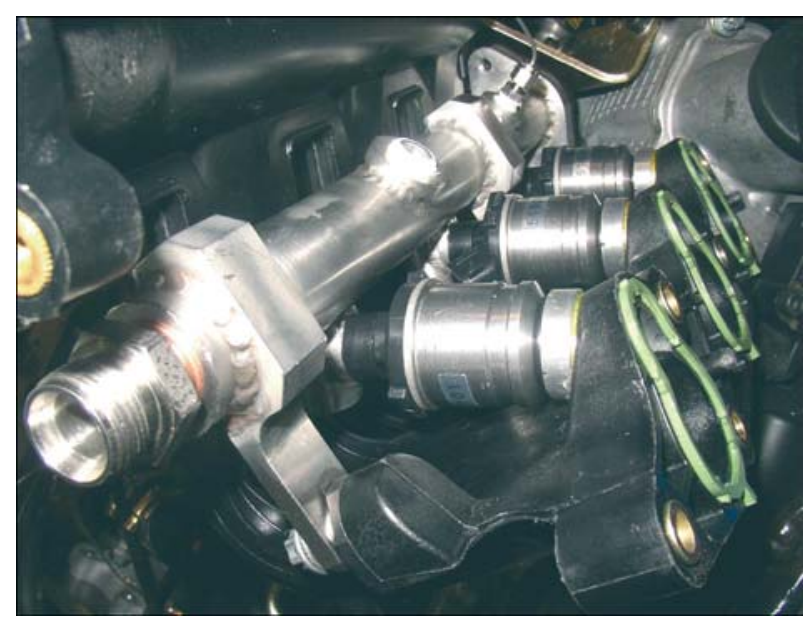

Picture 2

Gas rail in connection with gas injectors. lower electrical power and help to reduce leakage after engine switch-off.

As shown in Picture 2, a special Natural Gas rail has been fitted on the intake manifold without any design modification.

Tests on the engine-bench were performed using the IFP in-house electronic management system ACEbox ${ }^{\mathrm{TM}}$ (Automotive Control Engine based on XPCtarget ${ }^{\mathrm{TM}}$ ), which is able to drive the engine on the bench as in a vehicle. Mappings on steady state conditions were optimised before implementing the data into the vehicle Electronic Control Unit.

Figure 4 compares Break Mean Effective Pressure versus engine speed at full load conditions, for Natural Gas and gasoline settings. From 2700 rpm to maximum engine speed, the turbocharger is able to compensate the volumetric efficiency drop, noticeable when using gaseous fuel. The maximum output-power is not affected. At lower engine speed, maximum torque is obtained at $300 \mathrm{rpm}$ higher than for gasoline. This difference can of course be partially removed with additional improvements (turbocharger geometry, electrical assistance, etc.) but it does not affect significantly the vehicle behavior.

Looking at thermal efficiency, the Natural Gas curve stands out from the gasoline curve with a favorable gap whatever the engine speed. From 2500 rpm, thermal efficiency obtained with Natural Gas is $25 \%$ higher than for gasoline, leading to a reduction of $\mathrm{CO}_{2}$ emissions close to $35 \%$, combining the effects of compression ratio, settings and the $\mathrm{H} / \mathrm{C}$ ratio. This good result is all the more advantageous that the swept volume is reduced (downsizing) and consequently, that high load is in demand.

Thanks to the high equivalence octane number, Natural Gas spark advances are optimal although the compression ratio of 12.0:1, leading to maximum torque, Figure 5. The gasoline spark advance on the reference engine must be reduced from $1800 \mathrm{rev} / \mathrm{min}$ (knock limit), and enrichment is rapidly necessary to control exhaust temperatures, which drastically increase when spark advances are delayed.

Stoichiometric conditions and Maximum Best Torque advances are therefore continuously used for Natural Gas conditions. Due to high load conditions frequently used on so small engine, those results lead to a huge thermal efficiency in real operating conditions while maintaining near zero emission, whatever the driving conditions are, when the catalyst is warm.

Results at part load conditions also distinguish the Natural Gas engine. Figures 6 compares at $2000 \mathrm{rpm}$ the results obtained with Natural Gas (compression ration: 12.0:1) and gasoline (compression ration: 9.5:1). Thank to the compression ratio, thermal efficiency for Natural Gas tests is significantly higher than for gasoline, while NOx and unburned hydrocarbons emissions are not significantly different from gasoline tests. The mass of unburned hydrocarbons captured in combustion chamber crevice increase during the compression 
Full load comparison

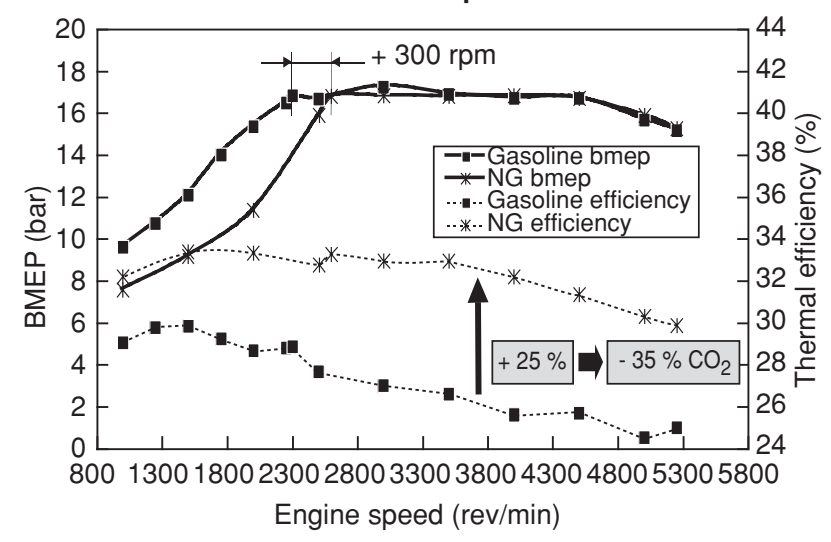

Figure 4

BMEP and thermal efficiency at full load condition (gasoline and Natural Gas).

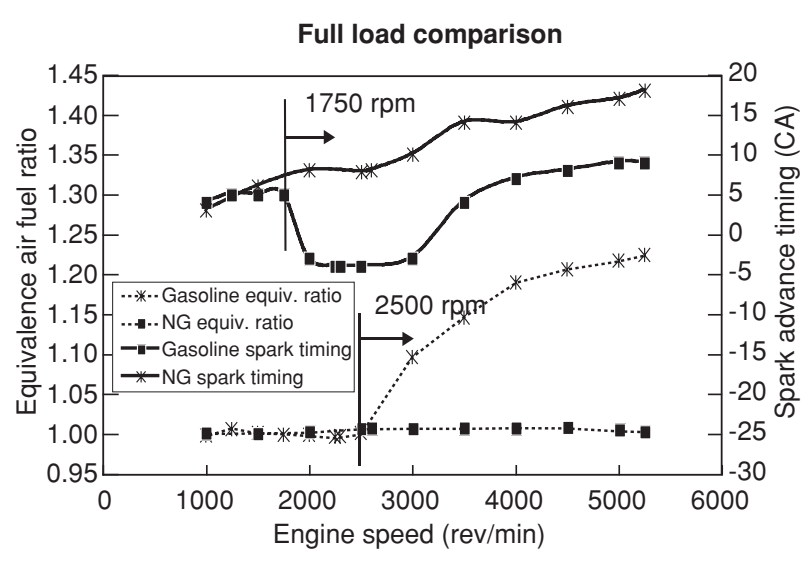

Figure 5

Equivalence ratio and spark timing at full load condition (gasoline and Natural Gas).

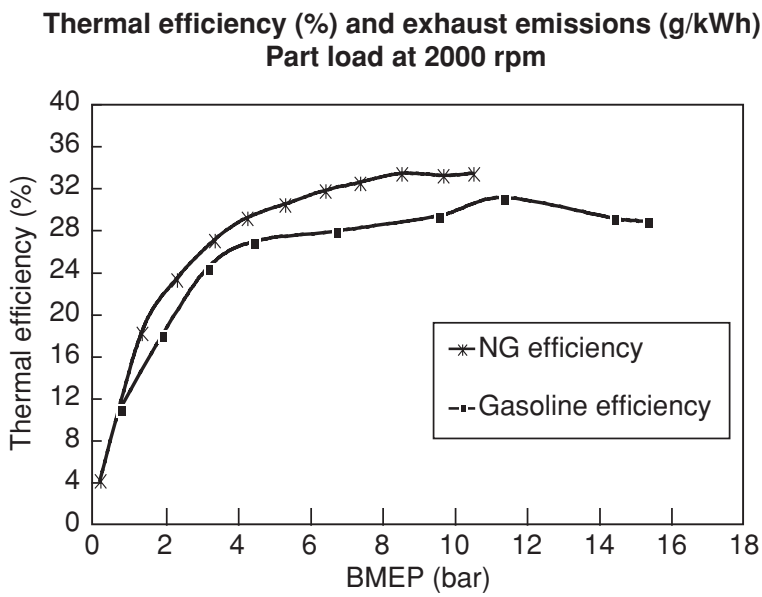

Figure 6

Thermal effiiency at $2000 \mathrm{rpm}$ (gasoline and Natural Gas).
In-cylinder Pressure (bar) at $2000 \mathrm{rpm}$ Part load conditions

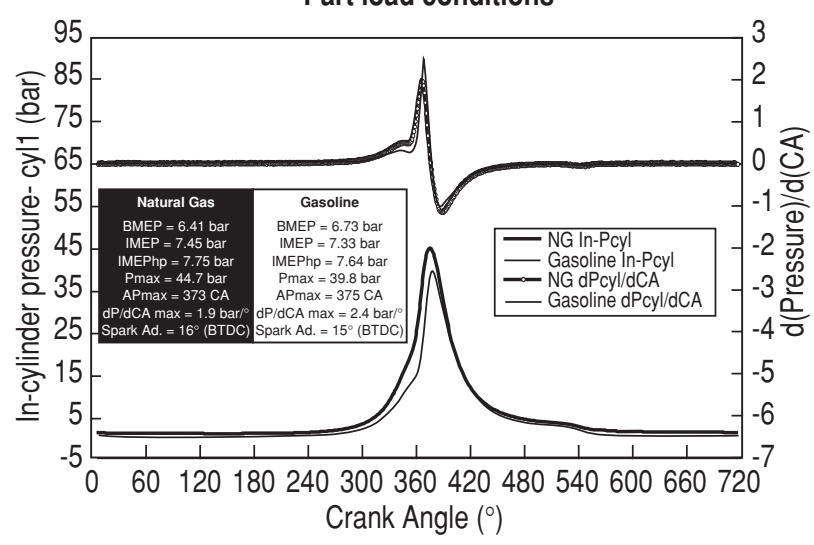

Figure 7

Combustion (gasoline and Natural Gas). stroke due to higher in-cylinder pressure. Notice that at this engine speed, the turbocharger is not able to compensate the drop of volumetric efficiency that occurs when using gaseous fuel. For 2000 rpm at full load, the maximum BMEP is consequently limited for Natural Gas test.

For a comparable load at $2000 \mathrm{rpm}$, Figure 7 compares the in-cylinder pressure curves during a cycle and the maximum of heat releases. Despite of a maximum of pressure obtained with the Natural Gas configuration and its higher compression ratio, the pressure diagram corresponding to maximum spark advance for best torque is worse than the gasoline one because of too much negative mechanical energy before top dead centre due to the slowest combustion speed of Natural Gas.
The difference between gasoline and Natural Gas brake thermal efficiency expressed in equivalent gasoline fuel consumption is plotted for the entire running conditions on Figure 8. As seen, the gasoline engine consumption is higher at low and high loads for each engine speed. The lowest difference calculated (based on steady state mapping) is $3 \mathrm{~g} / \mathrm{kWh}$ at $1500 \mathrm{rev} / \mathrm{min}$ and a Brake Mean Effective Pressure of 8 bars (star mark). Some steady state running points corresponding to conditions encountered on the NEDC cycle are plotted (circle marks), mainly located in the highest difference area. As shown, fuel economy is sensitive both on the NEDC cycle and all the more at maximum power conditions. 


\section{RESULTS OBTAINED WITH THE NATURAL GAS SMART ON CHASSIS-DYNAMOMETER BENCH}

The Smart itself has been modified as a special Natural Gas urban vehicle. The main modifications concern the original driven gearbox, setting up of the gas tanks high-pressure line. Finally, the gas engine was installed in the vehicle with the in-board electronic management system developed by IFP in partnership based on the ACEbox ${ }^{\mathrm{TM}}$ device.

\subsection{Gear Box Adaptations}

For a simple gearbox control without any special Electronic Management System, the electrical engine that sets the gear forks in motion has been removed and replaced by a classical mechanical system. The clutch mechanism also driven by the electrical engine is not modified, except for its control, which is done by an additional EMS developed especially for this application.

As seen in Picture 3, an additional pedal is installed for clutching operations.

\subsection{Setting Up the Natural Gas Tanks}

Three tanks built with a composite material have been designed and realized by ULLIT. Located in the chassis, Picture 4, the ground clearance and volume of the boot are not modified. A metallic shell covers the tank during running conditions (removed on this picture).

The total storage capacity is 35 liters, which represents on an NEDC cycle and for $20 \mathrm{MPa}$ gas pressure, a driving range of approximately 180 kilometers (for a vehicle quoted $\left.100 \mathrm{~g} \mathrm{CO}_{2} / \mathrm{km}\right)$.

\subsection{On-Board Management System}

The vehicle's on-board management system is composed of a Supervisor computer located in the boot and a Sequencer computer, located behind the front right seat, in charge of timing and of input/output signal management, Pictures 5 and 6.

The luggage space available is not affected, especially as the supervisor computer (the biggest one) will be removed at the end of the optimization tests.

The Natural Gas Smart has been presented in 2004 at the Paris World Auto-show ("Gaz de France" booth) and at the Pollutec Exhibition.

Today, the $\mathrm{CO}_{2}$ emissions on the NEDC cycle are already lower than $100 \mathrm{~g} / \mathrm{km}$, Table 4, which corresponds to a total reduction of $27 \%, 23 \%$ of which is due to Natural Gas and $5 \%$ to engine optimization.

Work is still on going to reduce regulated emissions and especially Unburned Hydrocarbons mainly composed of methane (>90\%). However, results obtained with a common gasoline exhaust line are similar to results for gasoline, Table 4. These results are really encouraging, but post-treatment remains an essential stage to succeed in lowering regulated exhaust emissions with a large margin.

TABLE 4

Smart results on NEDC with gasoline exhaust line

\begin{tabular}{l|c|c|c|c}
\hline & $\begin{array}{c}\text { CO } \\
\mathrm{g} / \mathrm{km}\end{array}$ & $\begin{array}{c}\mathbf{H C} \\
\mathrm{g} / \mathrm{km}\end{array}$ & $\begin{array}{c}\text { NOx } \\
\mathrm{g} / \mathrm{km}\end{array}$ & $\begin{array}{c}\mathbf{C O}_{\mathbf{2}} \\
\mathrm{g} / \mathrm{km}\end{array}$ \\
\hline Euro IV - 2005 & 1.00 & 0.10 & 0.08 & \\
Gasoline (IFP) & 0.30 & 0.09 & 0.04 & 136.4 \\
Natural Gas (IFP) & $\mathbf{0 . 3 1}$ & $\mathbf{0 . 1 1}$ & $\mathbf{0 . 0 5}$ & $\mathbf{1 0 0 . 0}$ \\
\hline
\end{tabular}

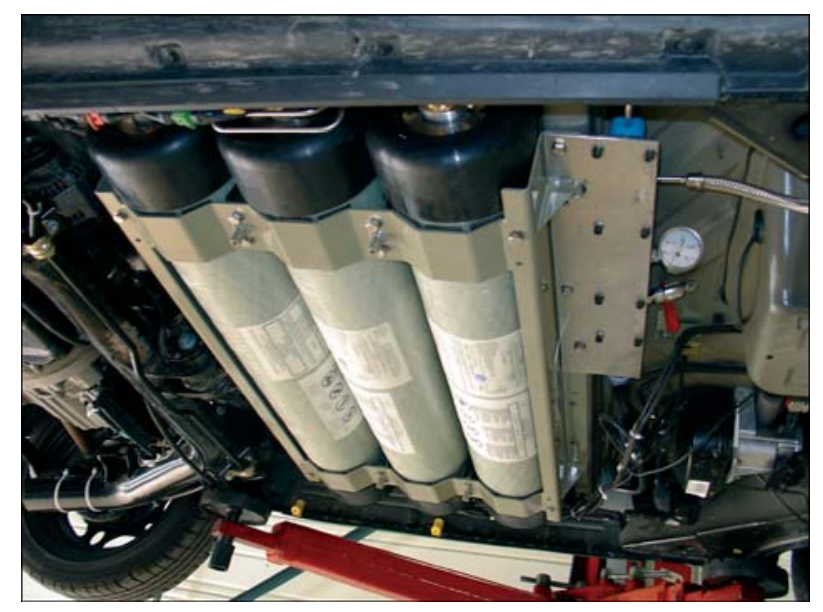

Picture 4

Under floor view.

Added clutch pedal on the left side. 


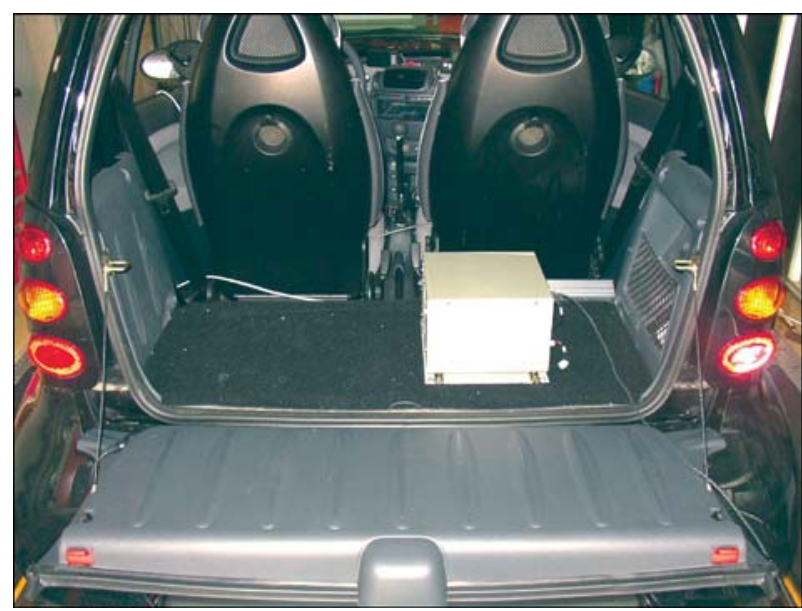

Picture 5

Boot with on-board EMS.

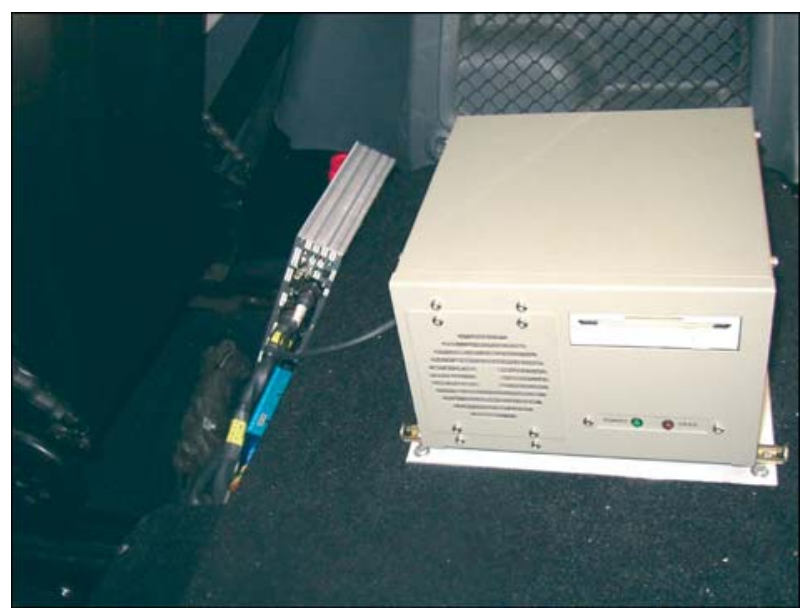

Picture 6

Supervisor and Sequencer computers.

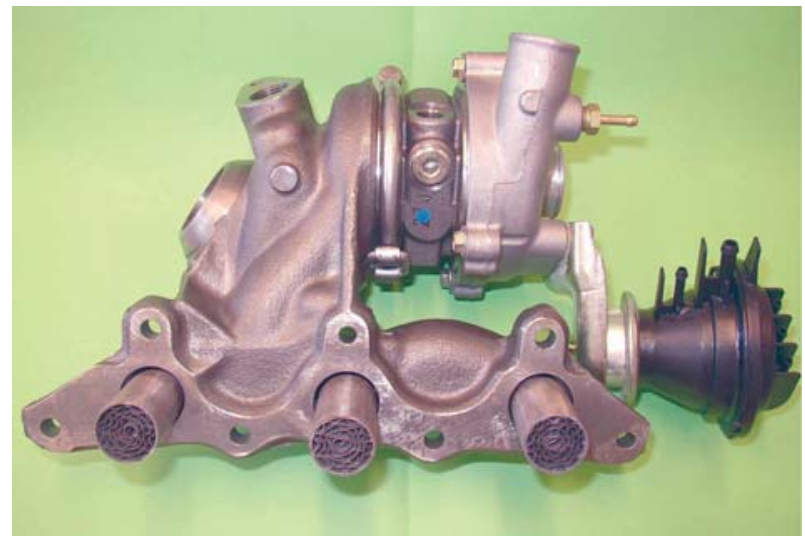

Picture 7

Metallic light-off implementation.

So, catalyst formulation and loading optimized for Natural Gas exhaust after-treatment are under assessment. Three small metallic converters (Bore $20 \mathrm{~mm} /$ Length $40 \mathrm{~m} /$ Volume $13 \mathrm{cc}$ ) are located between the cylinder-head duct and the exhaust manifold, Picture 7. Loaded with the same formulation, they should improve after-treatment efficiency, especially during the critical first seconds after start-up. Final results are expected by the year 2005 .

\section{EFFECT OF DRAG AND FRICTION LOSSES CURVE}

As previously mentioned chassis-dynamometer results reveal that the tested gasoline Smart vehicle emits $\mathrm{CO}_{2}$ emissions

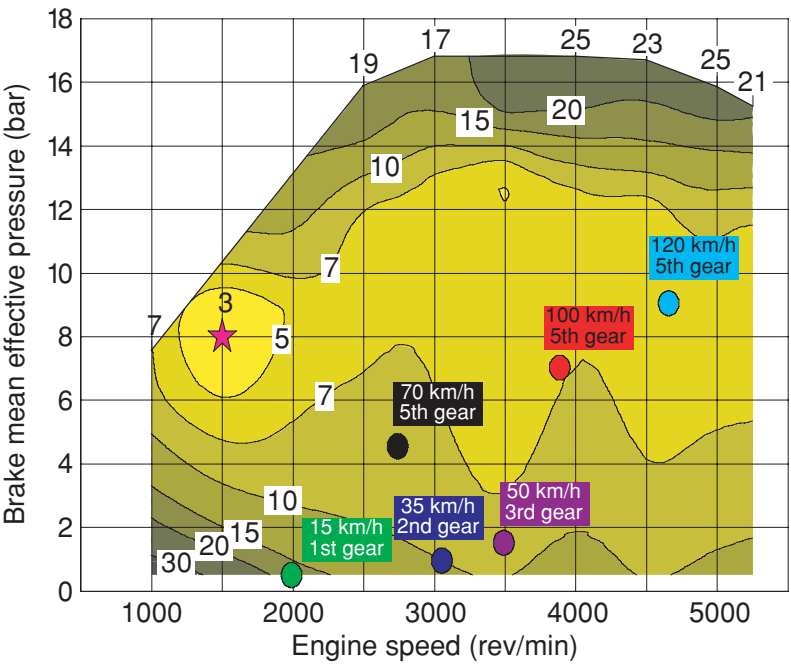

Figure 8

Equivalent gasoline BSFC difference between gasoline and NG engine.

over the official figure. This difference is probably due to friction loss difference.

To be able to estimate the real potential of the Natural Gas Smart Demonstrator, the calibration of the chassis-dynamometer bench has been adjusted to measure the official emissions, $118 \mathrm{~g} \mathrm{CO}_{2} / \mathrm{km}$ instead of $136 \mathrm{~g} \mathrm{CO}_{2} / \mathrm{km}$. As seen on Figure 9, the Natural Gas Smart Demonstrator potential is lower than $90 \mathrm{~g} \mathrm{CO}_{2} / \mathrm{km}$, more efficient than the Smart Diesel version. 


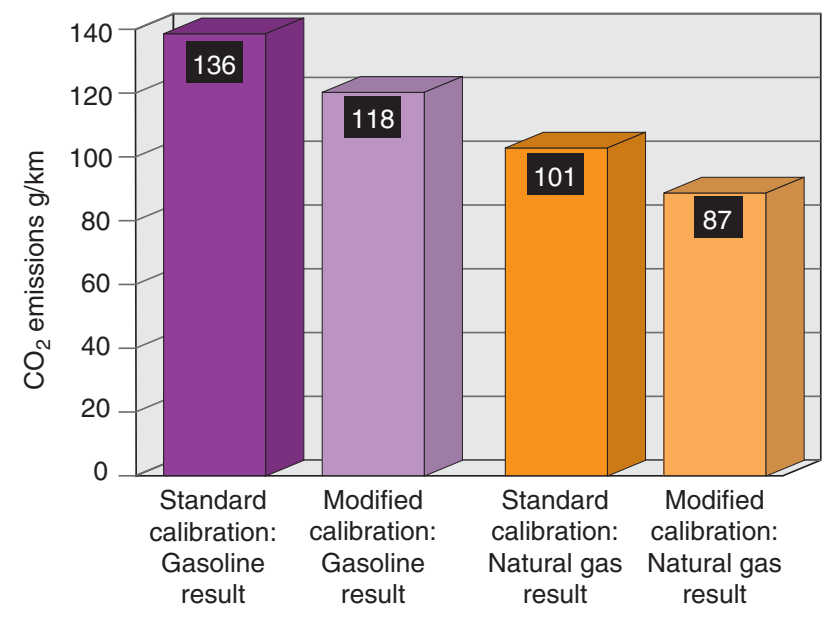

Figure 9

Chassis-dynamometer Bench calibration.

\section{CONCLUSION}

The partnership between Gaz de France and IFP with funding from $A D E M E$ confirms the great interest of Natural Gas used as a special fuel for downsized engine.

Important reductions of $\mathrm{CO}_{2}$ emissions on the NEDC cycle $27 \%$, and $35 \%$ for full load conditions have been obtained. Regulated emissions with the conventional gasoline exhaust line are close to gasoline emissions: the next calibration tests with special after-treatment should drastically reduce those emissions.

New gas tanks made of composite material are set up so that previous space inside the vehicle is not affected. The weight overload is limited to $40 \mathrm{~kg}$.

Drive-ability and driving range are in accordance with "urban" expectations

Finally, the development of the NG Smart demonstrator copes with IFP strategy since the Natural Gas pathway is one of the most efficient ways to reduce both greenhouse gases and pollutant emissions from transportation.

\section{ACKNOWLEDGEMENTS}

The Authors would like to thank technical and financial partners and all colleagues from IFP involved in the projects.

\section{REFERENCES}

1 Heitzer, M., Langen, P., Kramer, F and Meyer, O. (2000) Achieving low emissions and high engine efficiency with natural gas. IANGV Yokohama.
2 Heitzer, M., Langen, P., Kramer, F. and Meyer, O. (2000) Achieving low emissions and high engine efficiency with natural gas. IANGV Yokohama.

3 Sun, X., Wiedmann, T. and Hussain, S., Fuel management and exhaust emissions of light-and heavy-duty trucks operating on CNG and LPG. SAE paper 971661.

4 Suga, T., Muraishi, T. and Bienenfeld, R. (2000) Potential of a low-emission natural gas vehicle for the 21 st century. IANGV Yokohama.

5 Tilagone, R., Monnier, G., Satre, A., Lendresse, Y., Personnaz, J., Cullerier, D. and Turin F., Development of a lean-burn natural gas powered vehicle based on a directinjection diesel engine. SAE paper 2000-01-1950.

6 Johansson, B. and Olsson, K. (1995) Combustion Chambers for Natural Gas SI Engines Part I : Fluid Flow and Combustion. SAE paper 950469.

7 Olsson, K., and Johansson, B. (1995) Combustion Chambers for Natural Gas SI Engines Part I : Combustion and Emissions. SAE paper 950517.

8 Tilagone, R., Monnier, G., Chaouche, A., Baguelin, Y. and De Chauveron, S. (1996) Development of a high efficiency, low emission SI-CNG bus engine. SAE paper 961080. Detroit (USA).

9 Gaz de France (1993) Combustibles gazeux et principes de la combustion (BT104).

10 Union européenne (2000) Bilan Auto-oil.

11 Cornetti, G. (1999) Alternative fuels : the natural gas. ATA, vol. 52, Nov.-Dec.

12 Cedigaz (2002) Natural gas in the world.

13 Guibet, J-C. (1997) Carburants et Moteurs, vol. 1 et 2.

14 Journal Officiel des Communautés Européennes, L107/10. Directive 2001/27/CE de la Commission du 10 April 2001.

15 Norm ISO 15403 (2000) Gaz naturel - Désignation de la qualité de gaz naturel pour usage comme carburant comprimé pour véhicules.

16 Norm ISO 6976 (1997) Gaz, naturel - Calcul du pouvoir calorifique, de la masse volumique, de la densité relative et de l'indice de Wobbe à partir de la composition.

17 IANGV (International Association for Natural Gas Vehicles (2000) Emissions report, part 2 : fuel properties.

18 Buthker, E. (2000) World Wide NGV standards and Regulations. Session 2A. IANGV.

19 AFGNV (Association Française du gaz naturel pour véhicules) (2001) Rapport d'activité.

20 Zanetta, P. (2001) GNV : une première étape est franchie. Pétrole et gaz informations, $\mathrm{n}^{\circ} 1755$.

21 Plouchard, G. (2002) Le gaz naturel véhicules : les enjeux énergétiques et environnementaux de son développement durable. Rapport du Groupe de travail Energie Environnement de l'AFGNV.

22 Nylund, N.O., Laurikko, J., Ikonen, M (2002) Pathways for natural gas into advanced vehicles.

23 Well to Wheel Energy use and Green Gas Emissions of Advanced Fuel/Vehicle Systems - North American Analysis. Argonne National Lab. vol 1-2 (2001).

24 Weiss, M.A., Heywood, J.B., Drake, E.M., Schafer, A. and AuYeung, F.F. (2000) On the Road in 2020. A life-cycle analysis of new automobile technologies. MIT EL 00-003.

25 Choudhury, R. (2002) Well to Wheel analysis of energy use and greenhouse gas emissions of advanced fuel/vehicle systems. 
26 Livre Blanc (2001) La politique européenne des transports à l'horizon 2010. L'heure des choix. European commission COM, 370.

27 Ly, H. (2002) Effects of Natural Gas Composition Variations on the Operation, Performance and Exhaust Emissions of natural Gas-Powered Vehicles. IANGV.

28 Livre Vert (2002)Vers une stratégie européenne de sécurité d'approvisionnement énergétique. COM, 321.
29 Orselli, J. (1992) Energies nouvelles pour l'automobile. European commission.

30 Rouveirolles, P., (2000) Les spécifications des carburants $G P L$ et GNV. Euroforum.

31 Douaud, A. (2001) Quelles énergies pour l'automobile de demain. SIA.

Final manuscript received in November 2005 work owned by others than IFP must be honored. Abstracting with credit is permitted. To copy otherwise, to republish, to post on servers, or to redistribute to lists, requires prior specific permission and/or a fee: Request permission from Documentation, Institut français du pétrole, fax. +33147527078 , or revueogst@ifp.fr. 